\title{
PETUNG BAMBOO STRIPS WOVEN REINFORCED EPOXY COMPOSITE (PeBaSWoREC): TENSILE STRENGTH ANALYSIS
}

\author{
ZULKIFLI DJAFAR
}

Department of Mechanical Engineering, Faculty of Engineering, Universitas Hasanuddin, Gowa, 92172, Indonesia

\begin{abstract}
Natural fiber, especially bamboo, which is abundant in Indonesia, has the potential to be developed as an engineering material by material engineering. One of them is engineering in the field of composites. Utilization of bamboo fiber as an alternative material can replace the function of synthetic fibers in a variety of industrial and household equipment. Selection of fibers in the field of composite synthetic fibers into natural fibers. Bamboo composite is the most developed material. This is evidenced by the many studies that have been carried out. The purpose of this study was to determine the magnitude of the tensile test due to the long immersion in river water (brackish water) with the tensile strength specimen testing method based on ASTM D638-02 type I standard. The results of this study showed that immersion in the 3-layer petung bamboo composite in the 2nd week with 10 ppm seemed to provide the greatest test results. The greatest tensile strength value is $78.71 \pm 4.36 \mathrm{MPa}$. These results make a valuable contribution with a percentage of $58.54 \%$ greater than the lowest value obtained. The smallest tensile strength value at week 8 with 10 ppm with a value of $33.21 \pm 1.34 \mathrm{MPa}$. The greatest tensile strain value also occurs in the 2 nd week with 10 ppm which is $1.29 \pm 0.22 \%$. These results make a valuable contribution with a percentage of $50.19 \%$ greater than the lowest value obtained. The smallest tensile strain value at week 6 with 10 ppm with a value of $1.29 \pm 0.22 \%$.
\end{abstract}

KEYWORDS: Petung Bamboo, Brackish Water, Tensile Strength, Tensile Strain

Received: Jun 08, 2020; Accepted: Jun 28, 2020; Published: Aug 19, 2020; Paper Id.: IJMPERDJUN2020822

\section{INTRODUCTION}

Since ancient times humans have been trying to create a variety of products consisting of a combination of more than one material to produce a strong material. Technology continues to be developed in human life and can bring new findings. In its development, material engineering is one of the fields that have rapid progress. In every material design, the selection of the right material is very influential in its use. Many variables can be modified in making the material according to the needs of the design and budget for obtaining optimal and efficient designs [1]. Bamboo can be categorized as composite plants, bamboo fiber as reinforcement, and lignin as matrix [2]. Bamboo has high rigidity and low density, so that bamboo becomes a strong but lightweight material [3]. Bamboo is a grasstype plant with a hollow in the middle of the stem and stem segments. Bamboo can grow in dry areas or areas that have lots of water. Noted in Asia alone there are $80 \%$ of bamboo species of the total number of species in the world [4].

Previously, there have been many studies using bamboo fibers by providing immersion treatment as well as combinations with various other materials such as matrix epoxy resin and polyester resin. Research on bamboo petung that has been given an alkaline solution and soaked in boiling water for 4 hours, then carried out the drying process using an oven with a temperature of $110^{\circ} \mathrm{C}$ for 24 hours. The tensile strength values obtained for ASTM 
D3039-00 specimens were (269 $\pm 124 \mathrm{MPa})$ [5]. Of all natural fibers (sisal, hemp, coconut belts, etc.), bamboo has maximum tensile strength along with the fiber. Bamboo has $60 \%$ cellulose with a much higher percentage of lignin, with a relatively small micro fibril angle [6,7]. This fact supports the high tensile strength [8] and has conducted research on Apus bamboo skin fibers. Tensile test results from this study indicate that the addition of fiber into the composite is very influential on the tensile strength. Other test results show that the maximum tensile strength of polymer composites with bamboo fibers with a composition of $10 \% 15 \%$ and $20 \%$ are $38.11 \mathrm{MPa}, 55.8 \mathrm{MPa}$, and 86.01 MPa respectively.

Weaving is one way to arrange bamboo slats into the shape we want. Weaving is a technique of connecting bamboo blades by crossing them off. Several models of woven patterns developed include plain weaving, basketball, satin, twill, and their combination. The stress caused by overlapping bamboo causes a large frictional force so that the woven will not change its shape even if pressed [9]. According to [10], in addition to the matrices and fibers in making composites, woven patterns also have an influence on the strength of composites. Tensile testing aims to determine the stress, strain, and modulus of elasticity of the material by pulling the specimen until it breaks. Tensile testing can be done with a tensile testing machine or with standard universal testing. The relationship between stress and strain in tensile loads is determined by the following formula [11].

Although the potential of natural fibers is very good for renewable materials in its application, there are still some major problems in natural fiber composites, a great variety of properties, and high water absorption [12]. Large variations in location, weather, harvest time, and processing will greatly affect the strength of natural fiber-reinforced composites. Natural fiber composites have a large absorption because of their hydrophilic nature which makes changes in the fiber itself, the bond between the fibers, the matrix, and the mechanical properties of the composite [13].

\section{RESEARCH METHOD}

\section{Material}

The material used in this study was Petung bamboo (Dendrocalamus asper) from Tana Toraja Regency, South Sulawesi, Indonesia. Petung bamboo is then selected and made into a woven type of Plain, Brackish water is obtained from the Tallo River in Makassar, South Sulawesi, Indonesia and the matrix used is thermoset plastic such as an epoxy resin (resin mixture and hardener) obtained from PT Justus Kimia Raya, Semarang with type Bisphenol-A Epoxy Resin type Bakelite EPR 174 and Versamid-140 Hardener Epoxy type Polyamide Resins; and it is then made into a mixture of epoxy resin and hardener resin at a ratio of 60:40. 


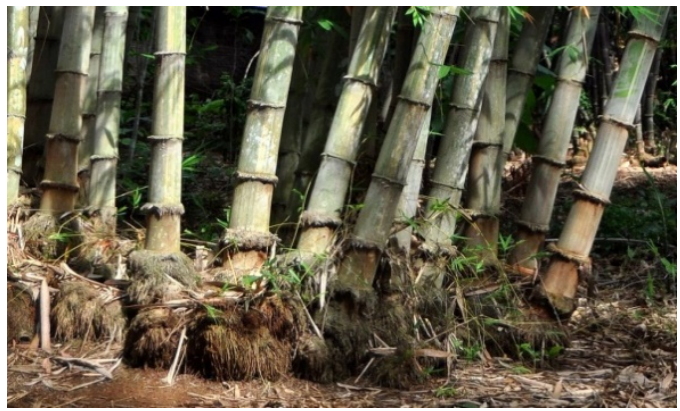

a.

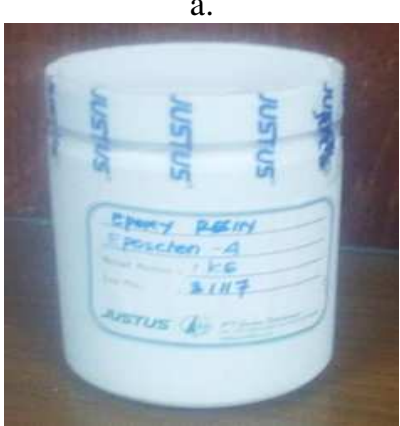

c.

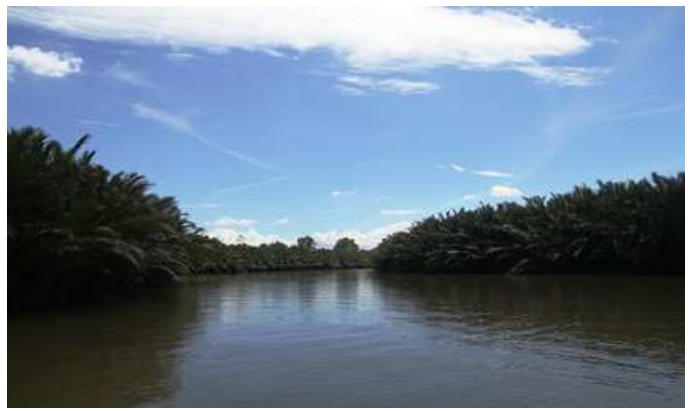

b.

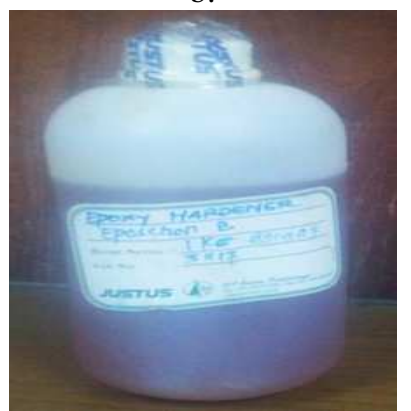

d.

Figure 1: (a) Petung Bamboo, Tana Toraja, (b) Tallo river, Makassar (c). Epoxy resin, and (d). Epoxy Hardener.

\section{Tools}

Molds made from steel with the size 250x250 mm; Aquarium, electric ovens, digital weighing scales, measuring cups 500 $\mathrm{ml}$, syringes $3 \mathrm{ml}$, (to measure catalyst); thermometers, calipers, chainsaws, sandpapers, and brushes and rolls.

\section{Testing Tools}

SEM-EDS analysis tool, FTIR analysis tool, and Tensile strength composite testing tool (ASTM standard D 638-02 type I) [14] are used in this research.

\section{Manufacture of Woven Petung Bamboo Strips}

Petung Bamboo used is taken from the stem with a distance of 2 meters from the base then the part is divided in a direction perpendicular to the bamboo skin with a thickness of $1 \mathrm{~mm}$ and a width of $10 \mathrm{~mm}$. The sheet is woven with a size of $250 \mathrm{x}$ $250 \mathrm{~mm}$, after the webbing is finished then it is immersed in a soaking container (laboratory scale) containing Tallo river water in Makassar, Indonesia. The salinity of the brackish water is increased to 10,20 , and 30 ppm with $0,2,4,6$, and 8 weeks immersion. 


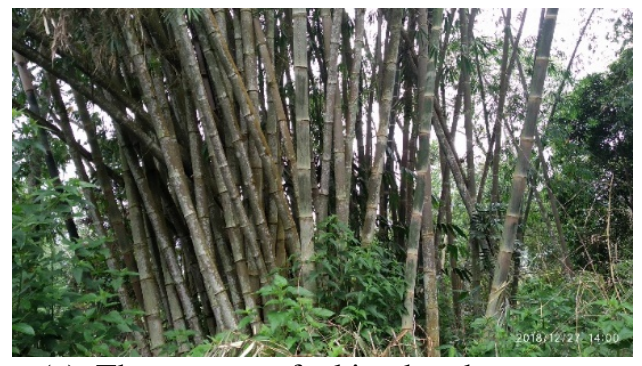

(a). The process of taking bamboo stems

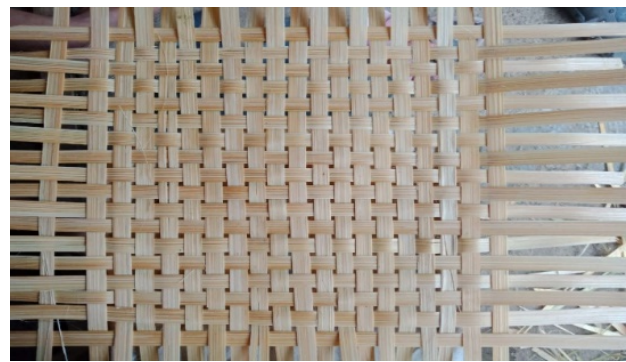

(b). Bamboo weaving process

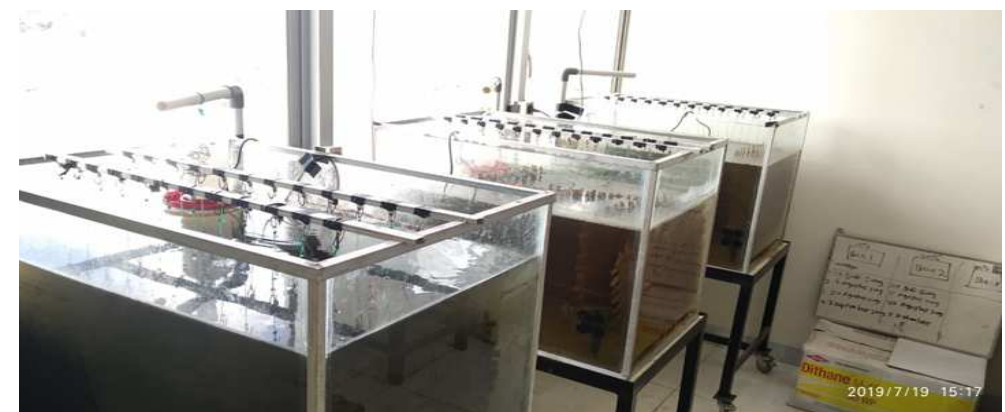

(c). Immersion of woven material under conditions of 10, 20, and $30 \mathrm{ppm}$.

Figure 2: The Process of Taking Bamboo Stems to the Immersion Process.

\section{The Molding Process}

The process of making bamboo petung composite panels used $250 \mathrm{~mm} \times 250 \mathrm{~mm}$ steel plate. The steps of molding this composite specimen are: the tools and materials used should be prepared, the first step begins with pouring the resin and hardener into the measuring cup according to the determined mixing ratio, then mix the resin and hardener on a container; stir the mixture until it is spread evenly. Afterwards, pour the mixture of resin and hardener adequately into the measuring cup; then spread evenly into the measuring cup until they are all filled evenly. Leave them for 3 up to 5 minutes; cover with one layer of petung bamboo strips woven and repeat up to 3 layers of bamboo woven. Cover the mold with the lid made from steel plate, and then press them with hydraulic press. This process is aimed to obtain a composite's standardized thickness. Wait for 6-8 hours until the mold is solidified. After they are all dry, the mold can be removed, (they are all still plates). The plates are then attached with pattern-drawn paper of tensile test based on ASTM standard (width, length, and thickness are all set appropriately), then cutting process uses chainsaw following the pattern drawn in the given picture; the result of the cutting is then finished by using sandpapers to smoothen the outer surface of the testing specimen. Afterwards, specimens are ready to be tested.

\section{The Process of Tensile PeBaSWoREC}

The process of making PeBaSWoREC tensile test specimens according to ASTM D638-02 type I standard; 7 specimens of bamboo petung were tested. All this is done to get a valid sample. By using a tensile testing machine, the M500-25CT Testometric model, a capacity of $25 \mathrm{kN}$., a Speed Range of 0.001 to $1000 \mathrm{~mm} /$ minute produced by Rockdale, Lancashire, England OL11 1NR.

\section{The Process of Testing Tensile Composite}

The process of producing tensile testing based on the ASTM D638-02 type I standard, with Distance Between Grips ( $\mathrm{D}=$ $115 \pm 5) \mathrm{mm}$, The width of a narrow section $(\mathrm{W}=13 \pm 0.5) \mathrm{mm}$, Width overall, $\min \left(\mathrm{Wo}_{0}=19 \pm 6.4\right) \mathrm{mm}$, Gage Length ( $\mathrm{G}=50 \pm 0.25) \mathrm{mm}$, Length of narrow section $(\mathrm{L}=57 \pm 0.5) \mathrm{mm}$, Length overall, $\min (\mathrm{Lo}=165) \mathrm{mm}$, Radius of the fillet 
( $\mathrm{R}=76 \pm 10 \mathrm{~mm}$, Thickness ( $\mathrm{T}$ ) adjusted with the testing material. The quantity of tensile specimens is 7 . This is aimed to obtain valid samples. By using tensile testing machine namely Testometric model M500-25CT, capacity 25 kN., Speed Range 0.001 to 1000 mm/min produced by Rockdale, Lancashire, England OL11 1NR.

\section{RESULT AND DISCUSSION}

\section{The Composite Tensile Strength}

Testing tensile stress and tensile strain of petung bamboo can be calculated according to ASTM D638-02 standards as in equations 1 and 2.

$$
\sigma_{c}=\frac{P}{A}
$$

Where: $\square \sigma_{\mathrm{c}}=$ tensile strength $\left(\mathrm{kg} / \mathrm{mm}^{2}\right), \mathrm{P}=\operatorname{load}(\mathrm{N}), \mathrm{A}=$ material cross-sectional area $\left(\mathrm{mm}^{2}\right)$. For tensile strain ( $\varepsilon$ ) fiber the magnitude can be determined using the equation.

$$
\varepsilon_{c}=\frac{\Delta L}{L}
$$

Petung bamboo tensile testing is intended to determine the mechanical properties of the material before it is used as a substitute material for wood in this case the hull body of the boat, sea boat and so forth. The results of tensile testing of petung bamboo strips include tensile strength, and tensile strain and are shown in Figure 3, and Figure 4 . Figure 3 shows the relationship between tensile stress and river immersion time with conditions of $10 \mathrm{ppm}, 20 \mathrm{ppm}$, and $30 \mathrm{ppm}$.

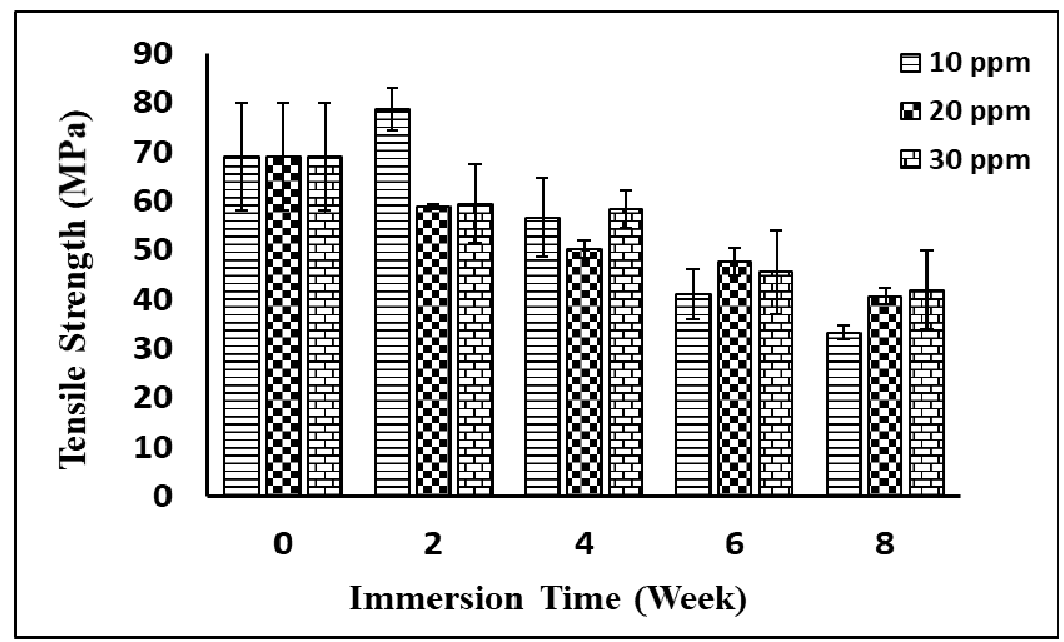

Figure 3: Relationship between Tensile Stress and Immersion Time in 3 Layers of Petung Bamboo-Composite Under Conditions of 10, 20, and 30 ppm.

In Figure 4, the relationship between tensile stress and immersion time on a 3-layer petung bamboo-composite at the 2 nd week with $10 \mathrm{ppm}$ seems to provide the greatest test results. The greatest value of tensile strength is $78.71 \pm 4.36$ $\mathrm{MPa}$. This result gives a valuable contribution to the percentage of $58.54 \%$ greater than the lowest value obtained. The smallest tensile strength value at the 8 th week with $10 \mathrm{ppm}$ with a value of $33.21 \pm 1.34 \mathrm{MPa}$, while the two types of immersion that are at $20 \mathrm{ppm}$ and $30 \mathrm{ppm}$ seen in the picture has decreased from the largest value at $20 \mathrm{ppm}$ is $68.95 \pm$ 10.94 $\mathrm{MPa}$ to the value the smallest is $40.63 \pm 1.69 \mathrm{MPa}$. It can be said that the percentage decrease in tensile strength is $41.07 \%$. Whereas for $30 \mathrm{ppm}$ the largest value was $68.95 \pm 10.94 \mathrm{MPa}$ and the smallest was $41.90 \pm 8.06 \mathrm{MPa}$ with a 
decreasing percentage of $39.23 \%$. Percentage decrease in tensile strength values of each type of $10 \mathrm{ppm}, 20 \mathrm{ppm}$, and 30 ppm immersion conditions are given with decreasing tensile strength values of $58.54 \%, 41.07 \%$, and $39.23 \%$ lower.

The results of this study are in line with Judawisastra et al. [5] saying that the degradation of the tensile strength of petung bamboo composites with random fibers due to immersion in hot water for 4 hours, bamboo strength has decreased the strength of the treatment given because water absorption occurs very quickly with increasing immersion time. According to Fattah et al.[15] in his research entitled "The Effect of Chemical Substance and Immersion Time of Dendrocalamus asper as Chemical Preservation Treatment" where bamboo is immersed in chemicals for 24 hours then the results obtained are concluded that the longer immersion carried out in chemicals will give the impact of degradation on the tensile strength of bamboo.

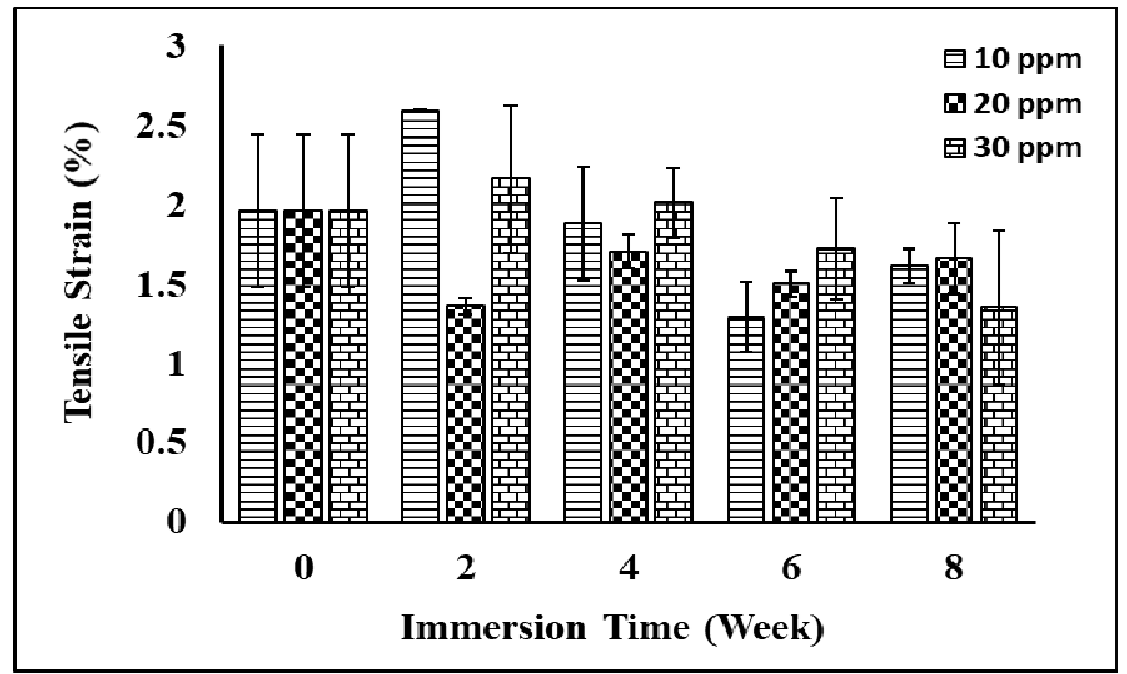

Figure 4: Relationship between Tensile Strain and Immersion Time in 3 Layers of Petung Bamboo-Composite Under Conditions of 10, 20, and 30 ppm.

In Figure 4, the relationship between tensile strain and immersion time in 3-layered bamboo composite, where the greatest tensile strain value also occurs at week 2 with $10 \mathrm{ppm}$ which is $2.59 \pm 0.01$. These results make a valuable contribution with a percentage of $50.19 \%$ greater than the lowest value obtained. The smallest tensile strain value at week 6 with $10 \mathrm{ppm}$ with a value of $1.29 \pm 0.22 \%$, while the two types of immersion namely at $20 \mathrm{ppm}$ and $30 \mathrm{ppm}$ seen in the graph decrease in strain value. For the largest strain value at $20 \mathrm{ppm}$ is $1.96 \pm 0.49 \%$ with the smallest value is $1.36 \pm$ $0.05 \%$. It can be said that the percentage decrease in tensile strain is $30.61 \%$. Whereas for 30 ppm the largest strain value is $2.16 \pm 0.46 \%$ and the smallest is $1.35 \pm 0.49 \%$ with a decreasing percentage of $37.50 \%$. Percentage reduction in tensile strain values of each type of immersion conditions of 10, 20, and $30 \mathrm{ppm}$ was given respectively 58.54\%, 30.61\%, and $37.50 \%$ lower. This value is in accordance with the existing theory that the magnitude of tensile strain is influenced by the tensile strength compared to the tensile modulus. The higher the tensile strength value and the lower tensile modulus value will create a high tensile strain value [16].

\section{FOURIER-TRANSFORM INFRARED SPECTROSCOPY (FTIR)}

Figure 5 is the PeBaSWoREC FTIR spectrum at 0 (normal), 10, 20, and 30 ppm, while Figure 6 is the PeBaSWoREC FTIR spectrum at 0 (normal), 2, 4, 6, and 8 weeks. It is known that the infrared absorption region is divided into two parts, namely the localized vibrational region, which is the absorption area of $4000-1500 \mathrm{~cm}^{-1}$ and the fingerprint region, which is the absorption area of 1500-900 $\mathrm{cm}^{-1}$. In Figure 5 and Figure 6 above, only the absorption area of $1500-900 \mathrm{~cm}^{-1}$ will be 
discussed, i.e. the localized vibrational region. The absorption area of $2500-4000 \mathrm{~cm}^{-1}$ formed O-H, C-H and N-H, functional groups. In the picture above, a peak of $3300-3500 \mathrm{~cm}^{-1}$ formed an $\mathrm{O}-\mathrm{H}$ group with widening physical appearance and strong intensity (wide and strong) and also occurred $\mathrm{H}_{2} \mathrm{O}$ crystallization in the absorption region 1640$1615 \mathrm{~cm}^{-1}$ (the strong absorption area due to water molecules). This was also made clear by research [17-18]. From Figure 5 and Figure 6, there is a shift in the peak to the left for the normal specimen spectrum with peak $2854.65 \mathrm{~cm}^{-1}$ in the absorption area $2500-4000 \mathrm{~cm}^{-1}$ shifting left from peak $2870.08 \mathrm{~cm}^{-1}$ to peak $2877.79 \mathrm{~cm}^{-1}$. Intensity obtained increased from $7.63 \mathrm{~cm}^{-1}$ to $10,596 \mathrm{~cm}^{-1}$ and the absorbance area decreased from $399.65 \mathrm{~cm}^{-1}$ to $347.953 \mathrm{~cm}^{-1}$. These results can be labelled in the form of correlations of wave numbers or frequency $\left(\mathrm{cm}^{-1}\right)$ with functional groups that are responsible for the absorption of infra-red radiation (IR) as shown in Table 1.

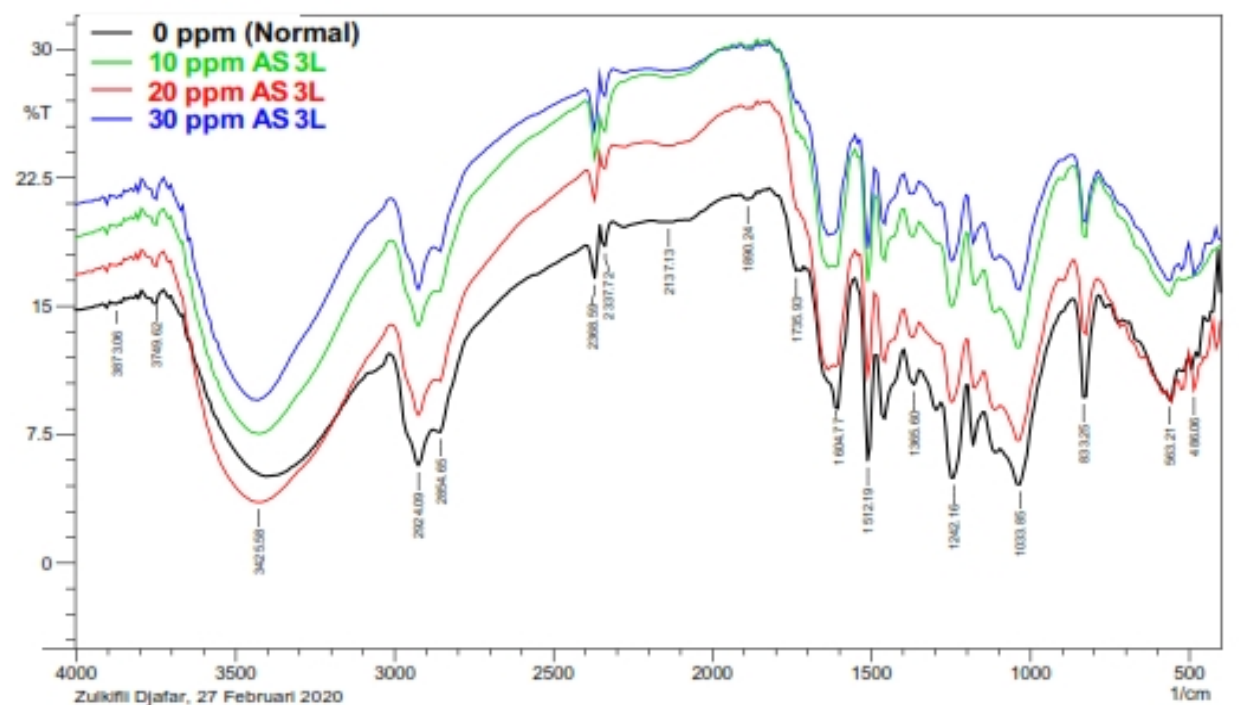

Figure 5: FTIR Spectrum of Brackish Water Immersion at 0 (Normal), 10, 20, and 30 ppm Conditions with 3 Layers Specimen.

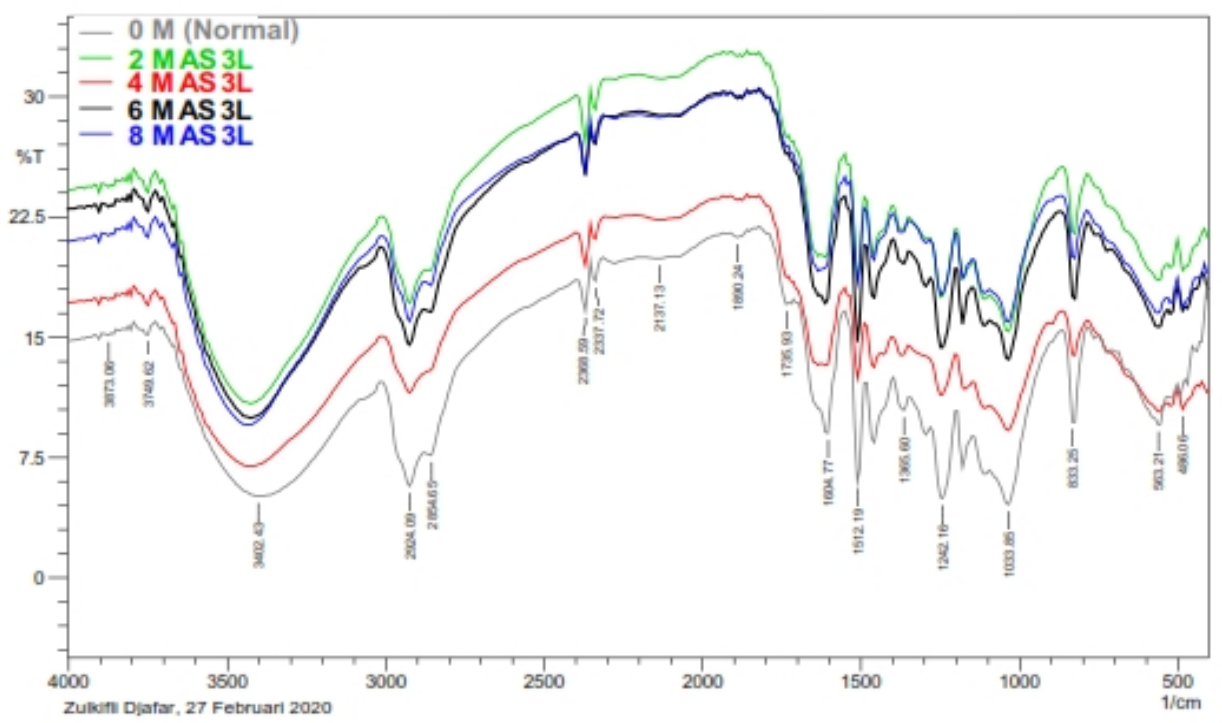

Figure 6: FTIR Spectrum of Brackish Water Immersion with Conditions 0 (Normal), 2, 4, 6 , and 8 Weeks with 3 Layers Specimen. 
Table 1: Correlations between Vibrational Types of Functional Groups and Frequencies

\begin{tabular}{|c|l|c|l|}
\hline Group & \multicolumn{1}{|c|}{ Vibration Type } & Frequency $\left.\mathbf{( c m}^{-1}\right)$ & \multicolumn{1}{|c|}{ Intensity } \\
\hline $\mathrm{C}-\mathrm{C}$ & Alkane's & 956,69 & Width - Weak \\
\hline $\mathrm{C}-\mathrm{N}$ & Amine & 825,53 & Sharp-Strong \\
\hline $\mathrm{C}-\mathrm{O}$ & $\begin{array}{l}\text { Alcohols, ethers, esters, } \\
\text { carboxylic acids, anhydrides }\end{array}$ & 1033,85 & Sharp-Strong \\
\hline $\mathrm{C}=\mathrm{C}$ & Aromatic alkaline & 1612,19 & Sharp-Strong \\
\hline $\mathrm{C} \equiv \mathrm{N}$ & Nitrile & 2337,72 & Sharp- Strong \\
\hline $\mathrm{C}-\mathrm{H}$ & Aliphatic and aromatic alkanes & $2800-3100$ & Sharp - Strong \\
\hline $\mathrm{N}-\mathrm{H}$ & Amida & $2500-4000$ & Medium \\
\hline $\mathrm{O}-\mathrm{H}$ & Phenol bound to hydrogen & $3300-3500$ & Width-Strong \\
\hline $\mathrm{H}_{2} \mathrm{O}$ & H2O from crystallization & $1640-1615$ & Strong \\
\hline
\end{tabular}

\section{SEM-EDS ANALYSIS}

From the results of Scanning Electron Microscopy with Energy Dispersive Spectroscopy (SEM-EDS) analysis morphologically; i.e. the composite test specimen was cut into $0.5 \times 0.5 \mathrm{~cm}$ size, then coated with Aurum (Au) for 120 seconds at a voltage of $20 \mathrm{kV}$, therefore the results of the composite SEM shown in Figure 7, where the ratio of epoxy resin and hardener amounted to 60:40 then added with petung bamboo as reinforcement as much as 3 layers and soaked for 8 weeks.
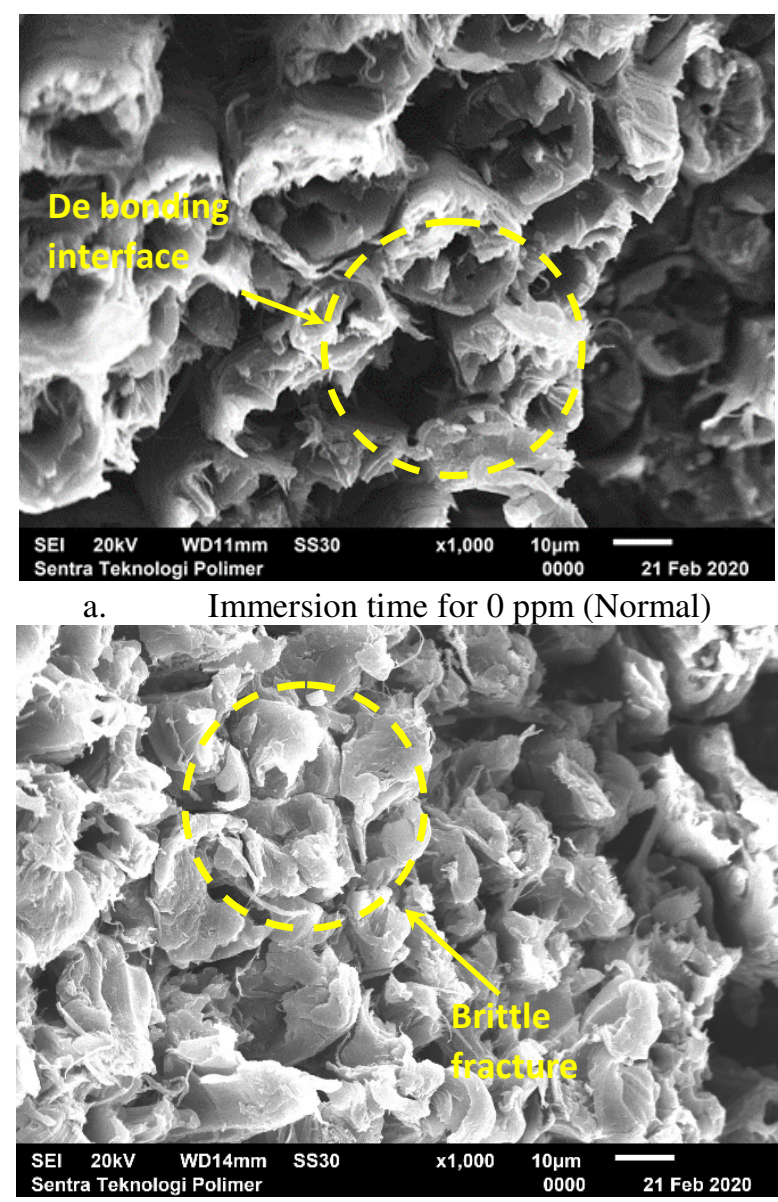

c. Immersion time for $20 \mathrm{ppm}$

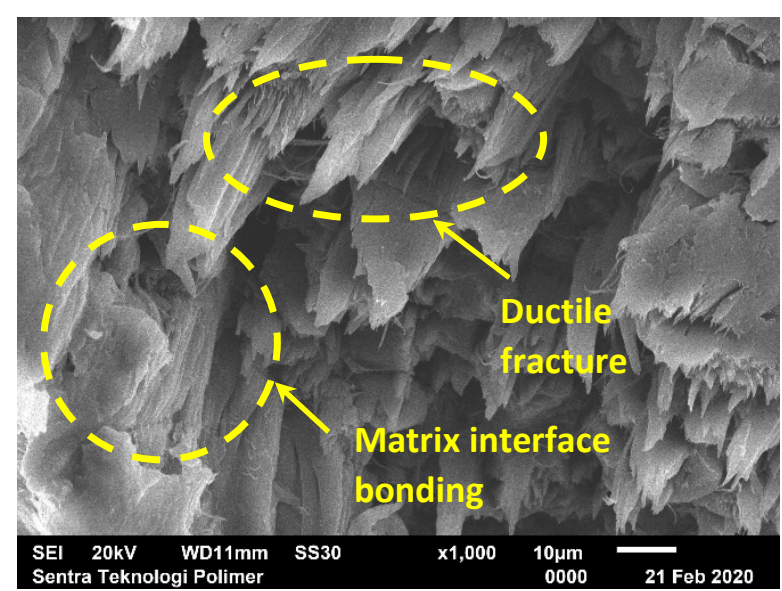

b. Immersion time for $10 \mathrm{ppm}$

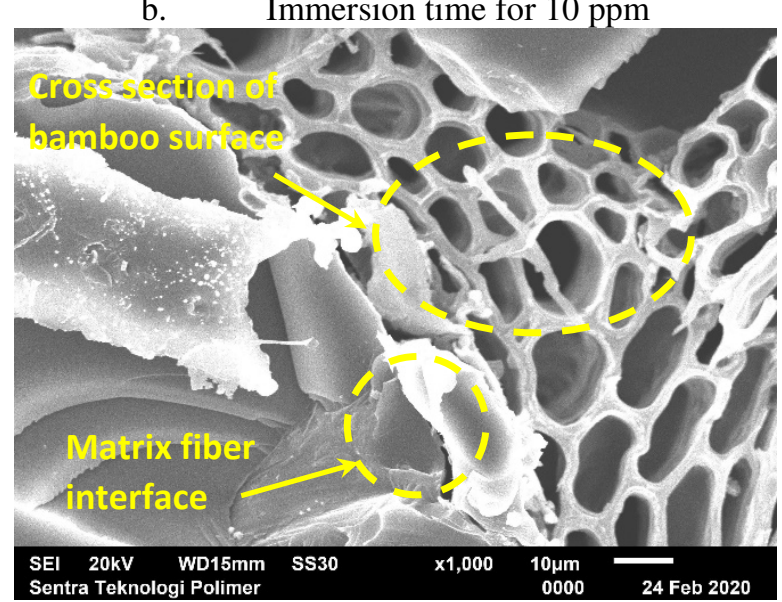

d. Immersion time for $30 \mathrm{ppm}$

Figure 7: SEM PeBaSWoREC in the form of 3 Layers with the Salinity of 0, 10, 20, and $30 \mathrm{ppm}$ for 8 Weeks. 
Figure 7 shown SEM photographic of PeBaSWoREC in the form of 3 layers with the salinity of 0, 10, 20, and 30 ppm for 8 weeks. SEM photo of 0 weeks or without immersion (figure a) shows the structure of the PeBaSWoREC fiber peeling from the matrix. The weak interfacial bonding between the fiber and the matrix, brittle fracture and some small holes in consequence of pullout. In figure $7 \mathrm{~b}$, a ductile fracture occurs, which results in the presence of several holes caused by pullout and PeBaSWoREC fibers apart from the matrix, and there is a little brittle fracture. The size of the PeBaSWoREC fiber appears to be expanding or increasing from its normal size. For figure 7c, the brittle fracture occurs and still cause the presence of several holes due to pulling PeBaSWoREC fibers (pullout). In figure 7d, we can see that the cross-section structure of the PeBaSWoREC fiber has several holes due to the non-entry of the matrix resin into the pores of the bamboo fiber cross-section, resulting in decreased strength.

\section{CONCLUSIONS}

From the discussion above, it was concluded that the results of the study showed that immersion in the 3-layer petung bamboo-composite for the 2 nd week with $10 \mathrm{ppm}$ seemed to provide the highest test results. The most excellent tensile strength value is $78.71 \pm 4.36 \mathrm{MPa}$. This result contributes to a percentage of $58.54 \%$ higher than the lowest value obtained. The smallest tensile strength value is found at week 8 with $10 \mathrm{ppm}$ with a value of $33.21 \pm 1.34 \mathrm{MPa}$. The highest tensile strain value also occurs in the 2 nd week with $10 \mathrm{ppm}$, which is $1.29 \pm 0.22 \%$. This result contributes to a percentage of $50.19 \%$ higher than the lowest value obtained. The smallest tensile strain value was obtained at week 6 with $10 \mathrm{ppm}$ with a value of $1.29 \pm 0.22 \%$.

\section{ACKNOWLEDGEMENTS}

We would like to express our deepest thanks and appreciation to the petung bamboo composite team to the brothers Chandra, Iqra, Imran, Zainal, Frans, and especially to Chandrabakty, and I also don't forget to thank the Mechanical Engineering Laboratory staff at Hasanuddin University for their help and support in this research.

\section{REFERENCES}

1. Nugroho, G., Wantogia M.S.R.R. (2019). Proses fabrikasidansifatmekanikkompositpolimerdenganmetode bladder compression moulding. Journal of Mechanical Design and Testing 1(2), 95-104.

2. Amada, S., Ichikawa, Y., Munekata, T., Nagase, Y. (1997). Fiber texture and mechanical graded structure of bamboo. Composites Part B: Engineering 28(1-2), 13-20.

3. Khosrow, G. (2005). Bamboo as reinforcement in structural concrete elements. Cement and Concrete Composites 27(6), 63749.

4. Dutta, Sushovan., and Jnanendra Nath Mandal. "Behavior of BambooGeocellsunder compression loading condition." Int J Civ Eng (IJCE) 2.3 (2013): 123-128.

5. Bethony, F.R. (2019). Analisistegangan bending danstrukturmikro strip bambupetung (dendrocalamus asper) akibatperlakuanperendaman air belerangdingin. Journal of Chemical Information and Modeling 53(9), 1689-1699.

6. Arbaeen, O., and Hind Mohammad. "CreatingContemporary Corset Designs, for Ladies' Clothing." International Journal of General Engineering and Technology (IJGET) 7.1 (2018): 21-34.

7. Judawisastra, H., Sitohang, R.D.R., Rosadi, M.S. (2017). Water Absorption and Tensile Strength Degradation of Petung Bamboo (Dendrocalamus asper) Fiber-Reinforced Polymeric Composites. Materials Research Express 4(9). 
8. Jain, Seema, Rakesh, K., Jindal, U.C. (1992). Mechanical Behaviour of Bamboo and Bamboo Composite. Journal of Materials Science 27(17), 4598-4604.

9. Shah, Meet P., Jayeshkumar R. Pitroda, and Jaydev J. Bhavsar. "Analysis of factorsinfluencingproductivity: Survey of construction projects in Central Gujarat Region of India." International Journal of Engineering Sciences \&ResearchTechnology 3.4 (2014): 3082-3087.

10. Jindal, U.C. (1986). Development and Testing of Bamboo-Fibres Reinforced Plastic Composites.” Journal of Composite Materials 20(1), 19-29.

11. Taufik, M., Sugiyanto, S., Zulhanif, Z. (2012). Perilaku Creep PadaKomposit Polyester DenganSeratKulitBambu Apus (Gigantochloa Apus (J.a\& J. H. Schultes) Kurz). JurnalIlmiahTeknikMesin FEMA 1(1), 97538.

12. Frick, Heinz. (2004). IlmuKonstruksiBangunanBambu. PenerbitKanisius, Yogyakarta.

13. Alimaskur. (2011). PengaruhSusunanBambuTerhadapKekuatanKompositBeton (Thesis S1). UniversitasAndalas, Padang.

14. Rabiul, S.M. (2013), AnalisaKekuatan Tarik Dan DensitasKompositPolimerBerpenguatSerbukCangkangTelur (Thesis S1). UniversitasHaluoleo, Kendari

15. Pickering, K. L., Efendy M.G.A., Le, T.M. (2016). A Review of Recent Developments in Natural Fibre Composites and Their Mechanical Performance. Composites Part A: Applied Science and Manufacturing 83, 98-112.

16. Amandine, C., Fréour, S., Jacquemin, F., Casari, P. (2014). The Hygroscopic Behavior of Plant Fibers: A Review. Frontiers in Chemistry 1(JAN), 1-12.

17. ASTM D 638-02. (2002). Standart Test Methode for Tensile properties of Plastic. American Sosiety for Testing materials, Philadelphia, PA.

18. Fattah,A.R., Prinindya, K.N.N., Ardhyananta, H. (2014). The Effect of Chemical Substance and Immersion Time to Tensile Strength of Bamboo Betung (Dendrocalamus asper) as Chemical Preservation Treatment. IPTEK, Journal of Proceeding Series 1, 119-124, E-ISSN. 2354-6026

19. Van vlack L.H. 2004. Elemen-elemenilmudanrekayasa Material. Erlangga. Jakarta. Indonesia.

20. Tsuboi, M. 1957, Infrared Spectrum and Crystal Structure of Cellulose, Journal Polymer Science, vol. 25, pp.159-171.

21. Liang, C. Y., and Marchessault, R. H. 1959, Infrared Spectra of Crystalline Polysaccharides, II: Native Cellulose in the Region from 640 to $1700 \mathrm{~cm}-1$, Journal Polymer Science, vol. 39, pp. 269-279 